\title{
Wioletta Krawiec
}

Uniwersytet Łódzki, Wydział Zarządzania

e-mail: wioletta.krawiec@uni.lodz.pl

\section{KREATYWNOŚĆ JAKO DETERMINANTA \\ TWORZENIA WARTOŚCI I POGLĘBIANIA \\ DOŚWIADCZEŃ JEJ ODBIORCÓW}

\section{CREATIVITY AS A DETERMINANT \\ TO CREATE VALUE AND DEEPEN \\ THE EXPERIENCE OF ITS RECIPIENTS}

DOI: $10.15611 / \mathrm{pn} .2018 .529 .11$

JEL Classification: M31, M15

Streszczenie: Celem artykułu jest ukazanie znaczenia kreatywności firm/osób i jej wpływu na konstruowanie nowych wartości i pogłębianie doświadczeń jej odbiorców. W opracowaniu nawiązano również do marketingu doświadczeń jako obszaru działań pozwalających w efektywny sposób wyeksponować twórcze i innowacyjne rozwiązania, mające na uwadze rosnące potrzeby i wymagania odbiorców w procesie pogłębiania własnych doświadczeń. Ujęto także aspekt umiejętnego zarządzania kreatywnością i doświadczeniami odbiorców, który umożliwia współczesnej firmie odniesienie sukcesu w różnych płaszczyznach kontaktu firmy z jej otoczeniem. Zaprezentowane przykłady z zakresu wyżej opisanych zagadnień pozwoliły zarysować ich znaczenie w procesie kreowania sukcesu firmy na płaszczyźnie: strategicznej, komunikacyjnej, wizerunkowej, produktowej, współpracy z otoczeniem itp.

Słowa kluczowe: kreatywność, innowacja, wartość i doświadczenie odbiorcy, zarządzanie, model, marketing.

Summary: The article shows the essence of companies / people creativity and its influence on the construction of new values and deepening the experiences of its recipients. The article also refers to the experience marketing as a place allowing to effectively expose creative solutions bearing in mind the growing needs of customers in the process of deepening their own experience. Skilful management of creativity and experience recipients allows a modern company to succeed in various areas of its operation. The presented examples on the issues described above have allowed to outline their importance in the process of creating the company's success on the strategic, communication, image, product (service), cooperation with the environment, etc. levels.

Keywords: creativity, innovation, value and experience of the recipient, management, model, marketing. 


\section{Wstęp}

Współczesne przedsiębiorstwo potrzebuje działań specjalistów, którzy myślą jak kreatywni innowatorzy i przedsiębiorcy. Zadania stawiane przed organizacjami wymagają tworzenia wartości dla klienta poprzez zaangażowanie się w działania całej organizacji (holistyczne ujęcie), jak i ludzi spoza niej. Powinno się zwracać uwagę na całościowe zarządzanie kreatywnością i doświadczeniem klienta, wykorzystując przy tym informacje w podejmowaniu decyzji oraz możliwości pomiaru efektów na podstawie wyników biznesowych.

W artykule skoncentrowano uwagę na kreatywności firm/osób jako ważnej determinancie w obszarze budowania innowacyjnych wartości i pogłębiania doświadczeń jej odbiorców. Dla tak sformułowanego celu w opracowaniu nawiązano do wymiarów kreatywności w firmie, które stanowią fundament przy opracowaniu innowacyjnych i przedsiębiorczych rozwiązań (wartości) w różnych obszarach działalności firmy, jak również przyczyniają się do pogłębienia doświadczeń jej użytkowników. Poruszono kwestie marketingu doświadczeń jako obszaru pozwalającego w efektywny sposób wyeksponować twórcze rozwiązania, mając na uwadze rosnące wymagania odbiorców w procesie pogłębiania doznań, wrażeń czy też silnych emocji. W artykule zwrócono również uwagę na istotę umiejętnego zarządzania kreatywnością i doświadczeniami odbiorców umożliwiającą współczesnej firmie odniesienie sukcesu na różnych płaszczyznach kontaktu firmy z jej otoczeniem. Zaprezentowane przykłady projektów z zakresu wyżej opisanych zagadnień pozwoliły autorowi artykułu odpowiedzieć na pytania: Jakie znaczenie dla współczesnej firmy ma jej kreatywność? Jakie efekty może przynieść kreatywne podejście do działań w firmie? Jak innowacje (kreatywne rozwiązania, nowe wartości) pozwalają pogłębić doświadczenie jej odbiorców?

\section{Kreatywność a budowanie wartości dla odbiorców i ich doświadczenia}

Modelowe ujęcie kreatywnego podejścia firm (podmiotów, osób) do tworzenia wartości dla odbiorców oraz możliwości pogłębiania przez nich swoich doświadczeń pozwala na uznanie jej za ważną determinantę mającą wpływ na sukces współczesnej organizacji. Kreatywność jest wielowymiarowym i niejednoznacznym obszarem pojmowania, a przez to różnie definiowanym przez badaczy [Sopińska 2018, s. 12]. Kreatywność można najprościej zdefiniować jako zdolność kojarzenia oraz wykorzystywania wiedzy z różnych dziedzin do tworzenia oryginalnych czy też nowych wartościowych rozwiązań. Nie ogranicza się tylko do generowania przełomowych innowacji. Może przysłużyć się do opracowania metody działania, rozwiązania jakiegoś problemu lub stworzenia nowego nawyku, sposobu życia [Kaczmarek-Kurczak 2014a]. Kreatywny człowiek posiada zdolność definiowania od nowa rzeczy znanych, wskazywania relacji między pozornie odległymi obiektami, posługiwania 
się przedmiotami w nowy sposób oraz nadawania im nowych znaczeń [Brzozowski 2015; Styś (red.) 2006]. Kreatywność jest częścią każdego człowieka, dysponuje on określonym potencjałem twórczym, wykorzystywanym w rozwiązywaniu niezliczonych codziennych problemów ${ }^{1}$. Dlatego też współtworzenie wartości z pracownikami, jak i otoczeniem zewnętrznym firmy może przynieść wymierne korzyści w postaci nowych rozwiązań (np. crowdsourcing, środowisko wirtualne) [Krawiec 2014, s. 101-114; Łaszkiewicz 2018, s. 29].

Kreatywność może być również źródłem wielu problemów i nieścisłości w firmie [Sopińska 2018, s. 12]. Dlatego też wymaga określenia jednoznacznych zasad jej wykorzystania i miejsc, w których powinna się pojawić (zarząadzanie kreatywnością). W artykule kreatywność ograniczono zatem do trzech obszarów: firmy (osoby, podmiotu), wytworzonej wartości jako efektu pracy kreatywnej (innowacji) oraz doświadczeń odbiorców tych nowych wartości.

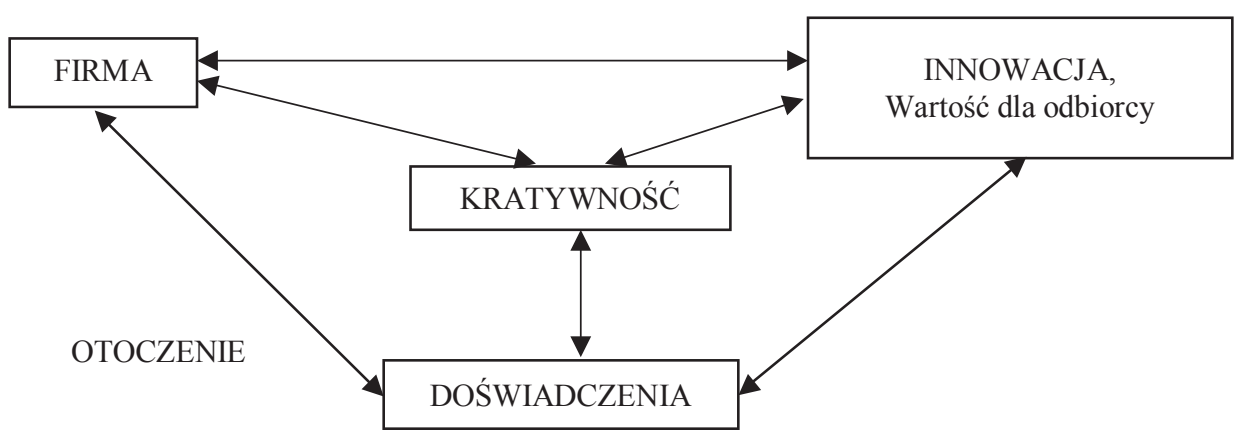

Rys. 1. Modelowe ujęcie kreatywnych działań firmy budujących wartość i doświadczenie odbiorców Źródło: opracowanie własne.

\subsection{Kreatywność firmy}

Kreatywność w firmie jest użyteczna w projektowaniu strategii, badaniach czy też procesach decyzyjnych. Może być ona również wpisana w misję każdej organizacji. Wymaga to jednak zarządzania kreatywnością i najczęściej ujmuje zarządzanie kapitałem intelektualnym firmy [Styś (red.) 2006]. Zarządzanie kreatywnością sprowadza się do zorganizowanego, celowego i systematycznego działania w kierunku pobudzenia pracowników i kierowania nimi w celu pozyskania nowych, wartościowych rozwiązań, przyczyniających się do osiągnięcia celów firmy. Jest to myślenie o kreatywności jako o stałym elemencie firmy, a nie przypadku. Aby móc mówić

${ }^{1}$ Około 70\% innowacyjnych pomysłów pochodzi od ,zwyczajnych” ludzi, a niekoniecznie od specjalistów danej dziedziny. 
o zarządzaniu kreatywnością w marketingu, należy mieć na uwadze jej wymiary, tj. 4P kreatywności: podmiot (person, jego wiedza, osobowość, umiejętność myślenia twórczego, motywacja wewnętrzna i zewnętrzna, podejście do rozwiązywania problemów; na poziomie kreatywności: indywidualnej, grupowej, organizacyjnej [Woodman, Sawyer, Griffin 1993]; ale również kreatywności: zespolonej, otoczenia [Brzeziński 2009]), proces (process, kreatywność incydentalna - rozwiązywanie problemów, np. burza mózgów w 80\%; kreatywność ciągła - wymaga misji organizacyjnej, systemu zarządzania, kultury i relacji wewnątrz firmy), uwarunkowania (press, otoczenie i kultura organizacyjna, przede wszystkim swoboda w działaniu [Wadden 2011, s. 73]) i wyniki (product, wyniki kreatywności i ich ocena). Marketing jako obszar działalności o znaczeniu strategicznym firmy w dużej mierze odpowiada za kształtowanie wartości dla klienta [Jerzyk 2017, s. 15-25]. Natomiast konieczność prowadzenia zintegrowanej komunikacji z rynkiem w równych płaszczyznach budowania dialogu z odbiorcą zmusza do poszukiwania kreatywnych rozwiązań prowadzących do skutecznego pozycjonowania i wyróżniania produktu czy marki (np. wykorzystanie marketingu doświadczeń).

\subsection{Innowacyjne rozwiązania}

Kreatywność w biznesie może być wykorzystana na różnych płaszczyznach działania, które przejawia się w tworzeniu nowych rozwiązań w procesie pracy (innowacja: produktowa, procesowa, organizacyjna, marketingowa itp. [Raport GUS 2013-2015]). Praktycznym wymiarem kreatywności jest innowacja, która może być nowym lub ulepszonym sposobem wykonywania czynności w celu udoskonalenia funkcjonowania organizacji jako całości. Może to być nawet drobna zmiana w sposobie wykonywania rutynowych czynności. Istotne jest to, aby innowacja dawała konkretne korzyści (wartości) dla człowieka czy firmy (przejaw przedsiębiorczości kreatywnej) [Kaczmarek-Kurczak 2014b, s. 34-62], które uzna on/ona za unikatowe, jednak muszą one pozostać w ich zasięgu, muszą być dostępne oraz dostarczone w odpowiednim czasie [Wanicki 2016, s. 515]. Innowacja powinna np. zwiększać wartość firmy, zysk, osobisty rozwój człowieka/pracownika, dawać większą satysfakcję z pracy/dobra czy użytkowania czegoś, powodować lepszą komunikację międzyludzką, poprawić wizerunek firmy czy powinna pozwolić opracować nowy model biznesu.

\subsection{Doświadczenie odbiorców}

Wykorzystanie kreatywnych rozwiązań w sferze marketingu jest konieczne z powodu chęci doświadczania przez klientów nowych wrażeń, emocji i przemian. Z drugiej strony coraz większy nacisk na pomiar efektów podejmowanych działań przyczynia się do planowania i zarządzania gromadzonymi przez klienta doświadczeniami (zarządzanie doświadczeniami klienta). Wymaga to wiedzy na temat m.in. bodźców marketingowych, które w kreatywny sposób pozwalają odbiorcy na pogłę- 
bianie wrażeń, zaspokajanie jego nieograniczonej potrzeby doświadczania czegoś oryginalnego, autentycznego, unikalnego. Dlatego też im głębiej dana innowacja „wchodzi” w strukturę codziennego życia odbiorcy (w jego strefę pracy, odpoczyn$\mathrm{ku}$, relacji z innymi, rozwoju itd.), tym więcej odbiorca gotowy jest w nią inwestować i ma problem ze zrezygnowaniem z niej. Współcześni konsumenci poszukują produktów/usług zestrojonych ze swoją tożsamością. Wszystkie działania, które mogą spowodować, że konsument uzna je za dopasowane do jego oczekiwań, aspiracji, potrzeb i niekoniecznie na podłożu jego doświadczania, pozwalają zatrzymać klienta przy firmie. Funkcjonowanie w obrębie marketingu doświadczeń wydaje się być zatem odpowiednim miejscem eksponowania kreatywnych działań. Jest wyjątkowym sposobem na budowanie, podtrzymywanie oraz systematyczne wzbogacanie i pogłębianie interakcji między firmą i klientem, bazując na wywołanych i zapamiętanych emocjach [Buguszewicz-Kreft 2009, s. 60]. Efekt ten można uzyskać dzięki wykorzystaniu kompozycji bodźców przekazywanych przez kreatywne i innowacyjne rozwiązania, które wywołują pożądane wrażenia (pozytywne, jak i negatywne), zwiększając zaangażowanie jej odbiorców.

Należy mieć na uwadze to, że marketing doświadczeń przenika przez różne obszary działań marketingowych. Na przykład koncepcja ta obejmuje dostarczenie doświadczeń przed samym aktem zakupu, w czasie sprzedaży, jak i po dokonaniu zakupu [Lendeman 2006, s. 10]. Marketing doświadczeń kreuje wrażenia klientów podczas kontaktów z produktem oraz w procesie komunikacji marketingowej [Sudolska 2011, s. 279]. Nacisk jest położony na ubogacanie działań marketingowych generujących silne odczuwanie przeżyć przez konsumenta oraz zapewnienie mu zabawy, które klient uzna za warte zapisania w swojej pamięci [Kotler 2004, s. 89-90]. W celu wywołania zjawiska powtarzalności zachowań konsumenta (np. powrót do sklepu itp.) istnieje konieczność dostarczania klientom silnych doznań już podczas generowania standardów gwarantujących maksymalizację jakości i powtarzalność usług [Gębarowski 2014, s. 152].

Kształtowanie doświadczeń klienta pozwala na zwiększenie satysfakcji nabywców, ograniczenie ilości nieproduktywnych działań oraz pozwala uzyskać oszczędności finansowe dla firmy [Shaw 2005].

\section{Projekty kreatywnie doświadczające - wybrane przykłady}

Zaprezentowane przykłady wdrożonych projektów obejmują wybrane obszary kreatywnego angażowania ich odbiorców, pozwalając im na pogłębianie wachlarza własnych doświadczeń. Przykłady te odnoszą się głównie do opracowanych modeli biznesowych organizacji, strategii komunikacyjnych, użytecznych rozwiązań życia codziennego człowieka w jego naturalnym otoczeniu, współtworzenia z odbiorcą kreatywnych rozwiązań, integracji i interakcji ludzkiej. Wybór tych przykładów był celowy i należy je traktować tylko jako źródło inspirujących działań dla firm/ludzi, które/-rzy chcą działać kreatywnie, zrzeszając dookoła siebie odbiorców akceptują- 
cych proponowane im rozwiązania/wrażenia. Przypomnieć należy, że kreatywność i doświadczenie mają złożony wymiar, a ich efektu końcowego nie stanowi koniecznie przełomowa innowacja lub też nieznane do tej pory uczucie (choć może wystąpić w innych miejscach, niż dotychczas odbiorca się mógł się spodziewać).

1. Projekty tzw. interakcji ucieleśnionej $\mathrm{w}$ otoczeniu organizacji, miasta, podczas konstruowania produktu, edukacji i utrwalania wiedzy itp. Opisane interaktywne projekty mają na celu pokazanie, jak w kreatywny sposób wywołać doświadczenie u jego odbiorców. Zakres ich zastosowania może być ogromny. Nie ma mentalnych granic, aby nie móc ich zastosować w organizacji firmy, budowaniu atmosfery i wizerunku firmy czy nawiązywaniu relacji z obcymi na pozór ludźmi na ulicy bądź pogłębianiu więzi z kolegami w firmie. Interaktywne projekty mają na celu głównie ,poczuć” nową technologię i widzieć jej użyteczność (wartość) w życiu codziennym. Powinna ona pozwolić się zrelaksować, uciec czy inspirować, wywołując efekt działania (kreatywne tworzenie). Współczesna firma zmuszona jest angażować odbiorców w ciekawy, oryginalny sposób, a rozwiązania technologiczne umożliwiają firmom osiągnięcie planowanego celu.

Jednym z takich kreatywnych przekładów jest projekt pt. System elewacji interaktywnej wraz z koncepcyjnym projektem architektonicznym pawilonu, jako jej przykladowe zastosowanie. Jest to projekt zwycięski w konkursie „Architektura w Nowej Skórze”, organizowanym przez magazyn „Architektura \& Biznes”. Projekt ten jest autorstwa Sylwii Kaszub oraz Iwony Kościółek. Konsultantem projektu był dr inż. arch. Krzysztof Kwiatkowski [www1]. Miejscem prezentacji tego projektu był Kraków, niezabudowany teren znajdujący się przy ul. Krupniczej. Pawilon zaprojektowano w charakterze plomby pomiędzy dwoma budynkami: Domem Literatów Polskich a Domem Józefa Mehoffera (Oddział Muzeum Narodowego). Stanowi on szlak komunikacyjny łączący miejsce zamieszkania studentów z uczelniami wyższymi oraz z rynkiem.

Projekt systemu elewacji pozwala zbliżyć się do architektury, dotknąć jej, poczuć detale opracowane z myślą o ludzkim ciele. Elewacja ta zachęca do integracji ucieleśnionej, a nie zamyka jej w umyśle bez szansy na fizyczne zaistnienie w rzeczywistości. Elewację stanowi duża ilość rurek zamocowanych w ścianie. W jej dolnej części rurki są ruchome, tzn. człowiek za pomocą dotyku może zmieniać ich położenie $\mathrm{w}$ ścianie $\mathrm{w}$ kierunku poziomym, a jednocześnie kształtować ją. Rurki można wpychać na drugą stronę ściany zarówno z zewnątrz, jak i z wewnątrz pawilonu, kształtując tym samym powierzchnię elewacji. Założeniem tego projektu było, aby człowiek mógł nie tylko zobaczyć architekturę, lecz aby również mógł ją poczuć, samodzielnie stworzyć oraz pozostawić po sobie ślad. Zostawić odcisk dłoni, ciała, emocji czy marzeń. Taka przestrzeń pozwala odkryć w sobie potencjał zmysłów oraz ukształtować wrażliwość na sztukę. Pozwala rozwijać kreatywność każdego użytkownika, nie tracąc własnej tożsamości. Bardzo ważne jest również myślenie o architekturze jako o organizacji przestrzeni życia człowieka, która powinna wyrażać dbałość o ład przestrzenny i środowisko naturalne. Projekt ten obok poznawania architektury zachęca do zdobywania nowych doświadczeń. 
Za inspirujący przykład może posłużyć projekt Magnetico opracowany przez Kamilę Koźmińską, Magdalenę Kurowską i Joannę Ziemowską. Instalacja Magnetico składa się z metalowych kulek, które początkowo tworzą płaską taflę [www2]. Jednak wyczuwając obecność człowieka, wchodzą z nim w interakcję. Stają się masą, z której można „lepić” przestrzenne formy. Im więcej osób znajduje się w pobliżu, tym bardziej „lepka” staje się masa i tym ciekawsze formy można uzyskać. Stworzone dzieło rozpada się, ponownie zamieniając w płaską taflę, gdy twórcy odejdą od obiektu². Jest to bardzo kreatywne rozwiązanie niewymuszonego zespołowego tworzenia, które zmienia zachowanie ludzi. Stają się oni zadowoleni, opada uczucie stresu, wstydu, bariery wchodzenia w relacje z ludźmi, którzy sami podchodzą do obiektu i którzy się nie znają. Produkt, który pozornie jest do niczego niepotrzebny, staje się źródłem budowania relacji ludzkich, uczenia się, wspólnego działania i tworzenia. Pozwala zrozumieć, że razem można zdziałać więcej.

2. Kreatywne projekty organizacji i jej pracowników pozwalające gromadzić doświadczenia jej użytkowników. Dotykać one mogą różnych obszarów działania firmy, np. opracowania kreatywnych modeli biznesowych, strategii działania, sposobów komunikowania się z odbiorcami lub angażowania ich w kreowanie określonego wydarzenia. Ten obszar działań wcale nie wymaga, jak we wcześniej przytoczonych projektach, nowych technologii. Może być skoncentrowany na kreatywności pracowników czy twórców w świecie realnym. Projekty te mają na celu głównie usprawnienie codzienności w pracy czy w domu. W świecie biznesu jedną z popularnych technik twórczego myślenia jest tworzenie za pośrednictwem technik design thinking czy metody IDEO itp. (mBank, Dell). Pozwalają tworzyć innowacyjne produkty i strategiczne rozwiązania. Projekt innowacji społeczno-środowiskowej, jak „Zielone dachy” w Infosys, jest przykładem pokazującym angażowanie pracownika w opracowanie miejsca odpoczynku do ich własnego użytku. „Banki idei" to głównie platformy do gromadzenia wiedzy od pracowników, ale i zewnętrznych odbiorców (Dell, Infosys, mBank i inni). Omnichannel to podejście służące do spójnej komunikacji z odbiorcami na płaszczyźnie offline i online [Gotwald-Feja 2017, s. 261-271].

Uosobieniem kreatywności i innowacji jest m.in. serwis internetowy Groupon (połączenie dwóch słów: gruop i coupon). Twórca, student Andrew Mason z Northwestern University w Chicago, wprowadził go w życie 2008 na terenie Chicago i w bardzo krótkim czasie serwis opanował inne państwa w świecie. Projekt rozwijał się skokowo, przejmując siostrzane projekty na jego przykładzie w innych krajach. Twórca projektu wymyślił, jak zachęcić ludzi do udziału w projekcie sprzedaży produktów i usług przy niskiej marży (rabaty sięgają 70-80\%). Myśl przewodnia: „Grupon to coś więcej niż wyjątkowe promocje, to wyjątkowy przewodnik po mieście". Grupon oprócz wymiernych wartości z zakupu towarów i usług po promocyjnych

2 ,School of Form (SOF) na Festiwalu Przemiany! 3-5.09.2015”, http://sof.edu.pl/aktualnosci/182wydarzenia-otwarte/2126-sof-na-festiwalu-przemiany.html (18.03.2018). 
cenach umożliwia ludziom poznanie miasta, w którym żyją. Stwarza znakomitą okazję do wypróbowania usług, o których nie wiedzieliśmy lub nie było nas na to stać.

Warto wspomnieć o zasadach, jakimi kieruje się Grupon. Sprzedaje rzeczy, które ludzie chcą nabyć. Dobra cena to punkt wyjścia, ale najważniejsze jest to, aby ten produkt/usługa był/-a oryginalna. Łącząc najlepszych partnerów biznesowych i najlepsze ceny, konsument ma czuć się wygodnie, odnajdując coś wyjątkowego, nowego, niepowtarzalnego. Kolejną zasadą jest zakaz „mydlenia oczu”. Oferty Gruponu muszą spełniać wiele kryteriów i jeżeli występują jakieś wady (np. niekorzystna lokalizacja), serwis zrobi wszystko, aby o tym poinformować klienta. Grupon przyjmuje również zasadę wysokiej jakości obsługi klienta. Obiecują szybką i przyjazną obsługę. Odwiedzając stronę Gruponu, faktycznie można się przekonać, że Grupon konsekwentnie wprowadza w życie swoje zasady [www3].

3. Projekty kreatywnego doświadczania dziedzictwa kultury, które pozwalają zwiedzającym i widzom gromadzić wiedzę o odwiedzanych miejscach, ale również w ciekawy, często zabawny oraz nieświadomy sposób wciągają odbiorcę w projekt. Komunikują się z klientem za pomocą niekonwencjonalnych form oraz w najmniej spodziewanym przez klienta miejscu. Pozwalają pracownikowi oraz klientowi tworzyć i produkować.

Za przykład może posłużyć Teatr Arlekin w Łodzi, który wdraża szereg kreatywnych działań, mających na celu wywołanie efektu głębokich doznań [www4]. Zakres ich eksponowania obejmuje środowisko wirtualne i rzeczywiste. Zaliczyć do nich możemy np. konkursy fotografii teatralnej, konkursy plastyczne, przebrania pracowników, parady na ulicach miasta, warsztaty, spotkania z artystami w centrach kultury, parkach, szkołach itp. Za przykład pogłębiania doznań widzów przez Teatr Arlekin można uznać m.in. niekonwencjonalny sposób promowania wydarzenia, wychodząc na ulicę, np. parada festiwalu otwierającego Międzynarodowy Festiwal Sztuki Animacji AnimArt [www5]. Ten sposób podejścia do odbiorcy przyciąga widza do teatru i buduje wizerunek Teatru w oczach mieszkańców i gości Łodzi. Ciekawym pomysłem był happening zapowiadający I Międzynarodowy Festiwal Animacji AnimArt, który odbył się na dworcu Łódź Kaliska [Cymkiewicz 2015]. Aktorzy ubrani w stroje sceniczne poruszali się między podróżnymi, wyskakiwali z pociągów i zaglądali przez szyby.

Ciekawy projekt wdrożył też Teatr Polski Bielsko-Biała - Wirtualny teatr polski [www6]. Jego celem jest edukacja medialna i informacyjna, pokazanie życia teatralnego od kuchni. Innowacyjna technologia filmu interaktywnego zapewnia widzom niespotykaną dotychczas możliwość interakcji i samodzielnego wpływania na oglądaną opowieść o życiu teatru i jego pracowników. Jest to projekt transmedialny, który składa się z filmu, zamieszczonych zdjęć i tekstu. Dzięki interaktywności widz ma możliwość wyboru oglądanej treści narracyjnie zbliżonej do gry wideo. Można poznać tajniki teatru, porozmawiać z poszczególnymi pracownikami, poznać specyfikę różnych zawodów, obowiązki pracowników administracyjnych, technicznych, podglądać próby do spektaklu, tworzenie dekoracji, szycie kostiumów, charakteryzację. 
4. Projekty ułatwiające pracę firmy z klientem i uwzględniające jego kreatywność (wspóltworzenie). Pozwalające na zobrazowanie przyszłych rozwiązań, np. prototypu produktu, wnętrza mieszkania czy firmy, z uwzględnieniem najmniejszych szczegółów, które wiernie odzwierciedlają realny obraz. Do takich projektów należy m.in. architektoniczny Virtual Real [www7]. Za pomocą VR można poczuć faktyczną przestrzeń domu, drzwi mogą się otwierać, telewizory włączać, a obiekty na półkach można przestawiać zgodnie z własnym pomysłem. Tego typu czynności pozwalają poczuć się, jakbyśmy w nim byli naprawdę. W przypadku produktu, np. prototypu głośnika, za pomocą VR można stworzyć jego wirtualną wersję, która pozwoli pobawić się jego funkcjonalnościami, podnieść go, zobaczyć z każdej strony. Poza tym firma organizuje imprezy okolicznościowe, pozwalając swoim klientom przenieść się wraz z bliskimi w świat wirtualny.

Na uwagę zasługuje również innowacyjny projekt Audi City, który ma na celu otwieranie $w$ dużych miastach świata salonów samochodowych pozwalających klientom zapoznać się z bogatą ofertą niemieckiego koncernu Audi w multimedialnym świecie 3D [www8]. Cybersalon można rozpoznać po ekranach cyfrowych, tzw. powerwalle. Na tych ekranach wyświetlany jest w skali 1:1 obraz samochodu marzeń, który klienci konfigurują, mając do wyboru całe mnóstwo wariantów. Można również z tego miejsca zlecić jego produkcję. Pierwszy salon sprzedaży sieci Audi City otwarto w roku 2012 w Londynie, a potem koncern zaczął otwierać kolejne: w Pekinie, Berlinie, Stambule, Paryżu i Moskwie. W parze z nimi rozwijane są cyfrowe technologie, które mają umilić klientom pobyt także w tradycyjnych salonach samochodowych.

\section{Zakończenie}

Kreatywność jest trudna do zdefiniowania. Spowodowane jest to tym, że odnosi się do osobistych stylów myślenia, ekspresji artystycznej, talentu, wrażliwości oraz inspiracji. Zazwyczaj zestawiane są one z kreatywnością. W tym ujęciu kreatywność stanowi determinantę formułowania nowych problemów, tworzenia innowacyjnych rozwiązań, które - aby można było uznać je za wartościowe - wymagają akceptacji ich odbiorców. Aspekt akceptacji innowacji wynika m.in. z tego, jak ta nowa marka, produkt zaprezentują swoją wartość. Pomocny może tu być obszar działań marketingowych z obszaru budowania doświadczeń, który pozwoli zaangażować i pokazać wartości płynące $\mathrm{z}$ nowych rozwiązań. Wymaga to po stronie organizacji umiejętnego zarządzania kreatywnością i doświadczeniem odbiorców nowych rozwiązań. Może to przynieść firmie wymierne efekty w postaci zaangażowanego środowiska pracy, bardziej zadowolonych i utożsamiających się z marką klientów, kreatywnych i chętnych do działania pracowników, ale również pozwoli opracować nowe modele biznesowe, poprawić komunikację we wszystkich punktach styku z firmą, projektować nowe i innowacyjne rozwiązania w strefie oferowanej, jak też organizacyjnej przedsiębiorstwa. Zakres kreatywności i dostarczanych wrażeń nie ma 
swoich mentalnych granic. Jedyne ograniczenia są natury materialnej oraz ludzkiej. Dla firmy istotne zatem jest określenie uniwersalnych bodźców lub też określenie ilości miejsc, w których może je eksponować. Natomiast zaprojektowane źródła doświadczeń powinny przełożyć się na zachowania jej odbiorców. Najważniejsze jest to, aby klient żył z organizacją i uczestniczył w jej wydarzeniach, bo największym sukcesem organizacji jest właśnie klient.

\section{Literatura}

Boguszewicz-Kreft M., 2009, Zarządzanie doświadczeniem klienta w ustugach, Wyd. Uniwersytet Gdański.

Brzeziński M., 2009, Organizacja kreatywna, PWN, Warszawa.

Brzozowski M., 2015, Kreatywność w zarządzaniu, Bank Spółdzielczy, nr 6/583, s. 12, https://www. bodie.pl/blog/kreatywnosc-w-zarzadzaniu,32 (28.04.2017).

Cymkiewicz Ł., 2015, AnimArt w Łodzi. Festiwal Teatru Arlekin, Naszemiasto.pl, http://lodz.naszemiasto.pl/artykul/animart-w-lodzi-festiwal-teatru-arlekin-zdjecia,3510963, artgal,t,id,tm.html (16.09.2015).

Gębarowski M., 2014, Shoppertainment oraz attainment - kreowanie wyjątkowych doświadczeń w handlu i gastronomii, Marketing i Rynek, nr 11, materiał na płycie CD, s. 152.

Gotwald-Feja B., 2017, Komunikacja marketingowa w realiach omnichannel-ujęcie modelowe, Marketing i Zarządzanie, nr 1(47), s. 261-271.

Jerzyk E., 2017, Wymiary kreatywności w obszarze marketingu, [w:] Kreatywność w praktyce biznesowej, red. J. Bieńkowska, Wyd. UŁ, s. 15-25.

Kaczmarek-Kurczak P., 2014a, U źródel kreatywnego świata. Ekonomia doświadczeń i jej oddziaływanie na kreatywne przedsiębiorstwa, [w:] OK! Oblicza kreatywności. Przedsiębiorczość w Sektorach Kreatywnych dla poczatkujacych $i$ zaawansowanych, red. P. Kaczmarek-Kurczak, K. Dąbrowska, Akademia Leona Koźmińskiego, Warszawa.

Kaczmarek-Kurczak P., 2014b, Kim sa przedsiębiorcy? Etapy powstawania kreatywnego biznesu alokacja zasobów, przedsiębiorczość, model biznesowy, [w:] OK! Oblicza kreatywności. Przedsiębiorczość w Sektorach Kreatywnych dla początkujacych i zaawansowanych, red. P. Kaczmarek-Kurczak, K. Dąbrowska, Akademia Leona Koźmińskiego, Warszawa.

Kotler Ph., 2004, Marketing od A do Z, Wydawnictwo Ekonomiczne, Warszawa.

Krawiec W., 2014, Skuteczny projekt crowdsourcingowy - przesłanki, wskazówki dla firm, przykłady wdrożeń, Organizacja i Kierowanie, nr 4, s. 101-114.

Lendeman M., 2006, Experience the Message, How Experiential Marketing is Changing the Brand World, Carrol \& Graf, New York.

Łaszkiewicz A., 2018, The use of creativity and intellectual capital of consumers in modern enterprises, Journal of Management and Financial Sciences, vol. XI, iss. 31, march, SGH, Warsaw, s. 27-35.

Raport GUS, Działalność innowacyjna przedsiębiorstw w Polsce w latach 2013-2015, s. 41-63.

Shaw C., 2005, Revolutionize Your Customer Experience, Palgrave Macmillan, New York.

Sopińska A., 2018, Kreatywność a innowacja organizacji. Otwarte innowacje jako przejaw wspótkreatywności, Studia i Prace Kolegium Zarządzania i Finansów. Zeszyt Naukowy nr 161, SGH, Warszawa, s. 11-27.

Styś. A. (red.), 2006, Proces kreatywności w marketingu, Wydawnictwo Akademii Ekonomicznej, Wrocław.

Sudolska A., 2011, Zarządzanie doświadczeniami klientów jako kluczowy czynnik w procesie budowania ich lojalności, Zeszyty Naukowe Uniwersytetu Szczecińskiego, nr 660, Ekonomiczne Proble- 
my Usług, nr 72, Marketing Przyszłości. Trendy. Strategie. Instrumenty. Zachowania konsumentów - trendy i kierunki zmian, red. G. Rosa, A. Smalec, I. Ostrowska, Wydawnictwo US, Szczecin, s. 279 .

Wanicki P., 2016, Innowacje jako źródło wartości przedsiębiorstwa, Prace Naukowe Uniwersytetu Ekonomicznego we Wrocławiu, nr 442, s. 510-518.

Wadden J.D., 2011, Marketing creativity: the influence of personal and proximal work factors on creative activity, Marketing Management Journal, vol. 21(2), s. 73.

Woodman R.W., Sawyer J.E., Griffin R.W., 1993, Toward a theory of organizational creativity, Academy of Management Review, vol. 18(2).

[www1] Archinea.pl, Współczesna Architektura. Polska i zagraniczna, Koncepcja pawilonu z interaktywna elewacja, http://archinea.pl/koncepcja-pawilonu-z-interaktywna-elewacja/ (17.03.2017).

[www2] Human Tech Art vol. 20, http://www.humantechart.pl/ (10.02.2016).

[www3] https://www.groupon.pl/ (30.05.2018).

[www4] http://www.teatrarlekin.pl (16.09.2015).

[www5] FB (Facebook), https://www.facebook.com/teatrarlekin (19.10.2015).

[www6] http://wirtualnyteatrpolski.pl/ (30.05.2018).

[www7] https://virtualhouse.pl/dla-biznesu/interaktywne-projekty-vr/ (18.03.2018).

[www8] http://innpoland.pl/132055,miasta-gdzie-jazda-to-nie-katorga-te-projekty-maja-spelnic-sen-kazdego-mieszczucha (30.05.2018). 